\title{
Leverage and investment opportunities: the effect on high growth firms*
}

\author{
Rossimar Laura Oliveira ${ }^{1}$ \\ (D) https://orcid.org/0000-0002-2632-8288 \\ Email: rossimar.laura@ifsp.edu.br
}

\author{
Eduardo Kazuo Kayo² \\ (D) https://orcid.org/0000-0003-1027-8746 \\ Email: kayo@usp.br
}

1 Instituto Federal de Educação, Ciência e Tecnologia de São Paulo, Departamento de Administração, Suzano, SP, Brazil
${ }^{2}$ Universidade de São Paulo, Faculdade de Economia, Administração e Contabilidade, Departamento de Administração, São Paulo, SP, Brazil

Received on 12.09.2018 - Desk acceptance on 01.18.2019 - $3^{\text {rd }}$ version approved on 08.02.2019 - Ahead of print on 12.09.2019

Associate Editor: Fernanda Finotti Cordeiro Perobelli

\begin{abstract}
The objective of this paper is to investigate if the high growth of a firm results in a reduction in its debt levels. This is expected to happen for firms that experience a positive idiosyncratic shock to their growth opportunities, which would affect their cash flow and profitability. Although the relationship between growth opportunities (e.g., Tobin's Q) and capital structure has already been widely discussed from a conceptual viewpoint, there are still important empirical gaps, particularly due to the endogeneity of the first variable. This paper seeks to minimize these problems by operationalizing the concept of idiosyncratic technological shocks. This issue is relevant because the negative relationship between growth and leverage may indicate that for the most efficient companies there will be a reduction in bankruptcy cost and a reduction in agency costs for the least efficient companies. This paper contributes to the development of studies in the area by demonstrating the inverse relationship between growth and leverage, with the model and the variable that represents the positive shocks experienced by companies. The dynamic panel method enables an analysis of the variation in debt in relation to the variation in value using the first differences and controlling the lagged debt effect. To apply the model, we used data from Brazilian companies, covering 1995 to 2016. The main results show that the greater the ratio between the firm's growth opportunities and its industry growth opportunities, the lower its leverage indicators. The complementary results suggest that less leveraged firms have this negative relationship to an even stronger degree.
\end{abstract}

Keywords: capital structure, investment opportunities, industry.

Correspondence address

Rossimar Laura Oliveira

Instituto Federal de Educação, Ciência e Tecnologia de São Paulo, Departamento de Administração - Campus Suzano

Avenida Mogi das Cruzes, 1501 - CEP 08673-010

Parque Suzano - Suzano - SP - Brazil

*Paper presented at the XLII ANPAD Conference, Curitiba, PR, Brazil, October 2018. 


\section{INTRODUCTION}

The idea that the choice of capital structure is a tradeoff between the tax benefits and the bankruptcy and agency costs and that there is a combination of these two factors that would maximize the firm's value is widespread, but the different studies have not yet reached a conclusion that fits all cases. This remains a relevant question, as a mistaken financial decision can cost a company's survival in the market.

Specific factors of the firm and of the environment have been tested over the years to address how companies make this decision and determine their debt levels. In this process, questions such as the availability of resources and costs being different, as well as political and legal differences if companies from different countries are compared, arise to cast doubts about the validity and generalization of the results.

The aim of this study is to investigate if the high growth of a firm results in a reduction in its level of debt. This is expected to occur for firms that experience a positive idiosyncratic shock to their growth opportunities, affecting their cash flow and profitability. A firm that sees an increase in its profitability may see its market value increase (Miao, 2005). To achieve this aim, we used data on Brazilian companies available from the Capital IQ database, excluding financial and regulated ones, covering 1995 to 2016. Abnormal growth was measured by the Tobin's Q (1969) of firm $i$ in relation to the mean Tobin's $\mathrm{Q}$ of the industry, excluding firm $i$. A positive value greater than 1 in this ratio may indicate that the firm experienced positive individual shocks and had investment opportunities that the other companies in the sector did not.

Although the relationship between growth opportunities (e.g., Tobin's Q) and capital structure has been widely discussed from a conceptual viewpoint, important empirical gaps remain, particularly due to the endogeneity of the first variable. This article seeks to minimize these problems by operationalizing the concept of idiosyncratic technological shocks.
The main aim is to analyze the effect of a variation in a firm's leverage in relation to the variation in its value and, for this, the generalized method of moments (GMM) of Arellano and Bond (1991) (AB) and that of Blundell and Bond (1998) (BB) were chosen. These methods enable an analysis of this variation using the first differences and control the effect of lagged debt, reducing the omittedvariable bias. For Nakamura et al. (2007), the GMM is recommended for dynamic panels because it includes specific company effects and time dummies, making it more efficient against endogeneity than merely using an instrumental variable not correlated with the error, which is a problem that using lagged debt can create. An additional result from using these models is it calculates the speed of adjustment of the capital structure.

The main results indicate that the greater the ratio between the growth opportunities of firm $i$ and the growth opportunities of its sector $j$, the lower its leverage indicators will be. The mediator in this relationship is the firm's value. Miao (2005) believes that the most efficient firms aim to keep their leverage levels lower. This is also what agency theory says, given that managers of firms with low investment opportunities may retain excessive cash flow values and issuing debt could be a disciplining factor, reducing the agency cost of free cash flow (Jensen, 1986). The complementary results suggest that the least leveraged companies have this negative relationship to a stronger degree. Additional results also show that the annual speed of adjustment of the capital structure of Brazilian firms is $56 \%$ and $83 \%$ of their leverage, according to the $\mathrm{BB}$ and $\mathrm{AB}$ methods, respectively, which is higher than the speeds found in previous studies.

This article provides indications confirming agency theory and contradicting trade-off theory, which will be addressed in section 2. Section 3 describes the methodological procedures used to achieve the research goal and section 4 presents the main and additional results and the discussion. Section 5 provides the concluding remarks. 


\section{THEORETICAL LITERATURE REVIEW}

\subsection{Trade-off between Benefits of Debt and Bankruptcy Costs}

The relationship between capital structure and value appears in some of the main theories: (i) the ModiglianiMiller (1958) theorem on the irrelevance of capital structure, in which a firm's value is equal to the market value of the total cash flows of its assets and is not modified by alterations in its capital structure; (ii) trade-off theory, from Kraus and Litzenberger (1973), which presents the idea that there is an optimal capital structure that maximizes the firm's value (companies pursue this ideal capital structure, adjusting their debt levels, balancing the tax benefits of paying debt interest and the bankruptcy costs, if the level of debt gets too high); (iii) agency theory, which suggests a positive relationship between debt and value, given that debt can reduce the problems of abnormal investments due to excess cash flow available under the managers' responsibility (Jensen, 1986); and (iv) market timing, which does not say that the capital structure will determine the firm's value, but that a company's capital structure is the product of the decisions of the managers that are monitoring the company's value in the capital market. These managers seek to use any privileged information they have about it to buy and sell shares according to their highs and lows (Alti, 2006; Baker \& Wurgler, 2002; Flannery \& Rangan, 2006).

Despite there being controversies, the evidence regarding the existence of an ideal capital structure is strong and a series of researchers present significant results concerning the speed at which companies adjust to this optimal level and concerning what factors determine whether the adjustment will be faster or slower.

These studies form part of the dynamic capital structure and show that this speed is between $7 \%$ and $30 \%$ per annum (p.a.), as in Fama and French (2002), Lemmon, Roberts, and Zender (2008), and Huang and Ritter (2009), though Flannery and Rangan (2006), who conducted one of the main studies on the subject, estimate an adjustment speed of more than 30\%. Denis and MacKeon (2012) reveal the non-existence of a target capital structure, but a structure that varies according to the need for funding and where the firm's debt capacity plays a relevant role in investment and financing decisions, which is a similar idea to the optimal interval and not optimal point of capital structure from Fischer, Heinkel, and Zechner (1989).
The proposed model, detailed in the Methodology section, considers that capital structure is dynamic and is a partial adjustment model. It is known that the capital structure is given by various characteristics of the firm (such as size, profitability, market-to-book [MTB] etc.) and that it is in an imperfect environment, with costs and benefits of operating with different levels of leverage. When a firm finds the debt level that balances these costs and benefits, it maximizes its value, which is the optimal leverage point. The speed of adjustment to the optimal level is defined according to the firm's adjustment costs. If there were no costs, firms would not deviate from their target, and if transaction costs were very high (tending towards infinity), firms would be unable to carry out any adjustment (Flannery \& Rangan, 2006). Confirming this position, for Leary and Roberts (2005), firms with reduced adjustment costs have a higher probability of responding to shocks to their leverage level than companies with higher adjustment costs and, in general, companies do not make adjustments often, but only once a year.

As seen, for Flannery and Rangan (2006), firms adjust their target capital structure by $34 \%$ p.a. on average, which contradicts those studies that have affirmed that this adjustment does not exist or that it would be very low. Their additional results show that overleveraged companies reduce their debt, underleveraged ones increase it, and the adjustment is quicker the greater the deviation from the target. This behavior does not change, independently of whether the company has a positive or negative deficit, such as in the aforementioned study by Flannery and Rangan (2006), in which companies with excess cash flow, but that were underleveraged, increased their debts.

When Denis and McKeon (2012) show that, unlike in many studies, firms do not manage their capital structure in the direction of a fixed leverage target but instead according to their operational financing needs, they propose the interpretation of this situation as a movement away from a possible ideal static structure. Their findings also show that financing flexibility is an important determinant of capital structure and that unused debt capacity is an important source of this flexibility.

The empirical results of Denis and McKeon (2012) say that changes in company leverage are related with changes in cash flow and in investment opportunities, which require operational financing. Companies took 
out more loans when they had a cash flow deficit, even when already above their leverage target, and companies with a cash flow surplus resolved to pay debts, even when below the leverage target, instead of making payments to shareholders, for example. The authors affirm that there are permanent and transitory components in debt composition. The permanent part would be related to the company's long-term goal and the transitory part to the operation; however this observed long-term adjustment is very slow, and so the authors were able to affirm that it is not a concern of companies to pursue a leverage target.

For Miao (2005), the standard trade-off model does not hold up against empirical studies that show that highgrowth companies have low leverage. Instead of the MTB ratio being positively related to the technological growth, it is negatively related to the leverage not only of the firm, but of the sector (Miao, 2005; Myers, 1977).

Although an increase in growth can reduce the present value of profits, if the companies in the sector are highly efficient, they and the sector will have a higher equity and market value. The growth will cause a fall in interest rates, reducing the tax benefit; an increase in the liquidation point, which is a lower chance of bankruptcy, has a selection effect, because to survive in the sector companies must have high productivity levels, which makes entry more difficult, reducing the rate of turnover.

\subsection{Trade-off between Agency Costs and Debt}

One way of preventing managers from misusing a firm's resources, whether by investing in negative net present value (NPV) projects, buying unnecessary assets, or holding excessive cash flow values, is to issue debts (Myers, 1977; Jensen, 1986). This manager position leads to an increase in their personal satisfaction, but reduces the firm's value.

Agency theory explains the positive relationship between value and debt using the hypothesis of debt's control over opportunistic manager actions, especially when free cash flow is high (Jensen, 1986), which occurs especially with mature firms (Jensen \& Meckling, 1976). Another question indicated in agency theory is that if the managers do not own part of the firm, they may be even more likely to engage in the highest possible amount of superfluous spending (Jensen \& Meckling, 1976; Saito \& Silveira, 2008).

The disciplining role of debt is characterized by the obligation to pay periodic interest with excess cash flow, reducing the amount available, and this benefit may be a determining factor of the optimal leverage level. Companies that have many investment opportunities with a positive NPV do not usually have excess cash flow, but for those that have few investment opportunities, excess cash flow may be expropriated from shareholders as a result of manager decisions. Thus, issuing debts creates the obligation to pay, reducing this agency cost by reducing the available cash flow under the managers' responsibility, which means that the disciplining effect of debt is a determinant of capital structure (Jensen, 1986).

D'Mello and Miranda (2010) tested the effectiveness of issuing long-term debt as a way of controlling the urge of managers to invest in projects that could result in a loss for investors. The authors state that there are indications to confirm the hypothesis of the disciplining role of debt in the following conclusions:

a. If the manager works in a low leverage company, he/ she holds an excessive amount of cash flow;

b. Three years after issuing debts, to avoid poor investments, the company's cash flow indices, which had excess value before, came close to the sector's value;

c. Using debt to avoid overinvestment has a greater impact on companies that have more agency problems and fewer investment opportunities;

$\mathrm{d}$. When the disciplining role of debt is absent, companies do not overinvest in real assets. Issuing debt will reduce excess capital spending, but will not eliminate it. A reduction in overinvestment is related with debtservicing obligations, since paying interest reduces excess cash flow and the amount available that can be misused by managers. Jensen (1986) had already said that the consequences of non-payment of debt services act as a motivating force in making companies more efficient. Jensen (1986) did not ignore leverage costs, even bankruptcy costs. Thus, as for trade-off theory, there is an optimal leverage point that maximizes the firm's value;

e. Companies that reduce their overinvestment in real assets and cash flow increase their market value;

f. If a company reduces or eliminates its debt, it will retain what would previously be used for interest payment, returning to overinvestment.

In summary, D’Mello and Miranda (2010) verified a fall in abnormal expenses, especially for companies with few investment opportunities, because debt obligations reduce the amount of money available under manager control.

The focus of this article is on the negative relationship between investment opportunities and leverage: companies with more investment opportunities will have fewer debts and companies with fewer investment opportunities will have more debts. D'Mello and Miranda (2010) tested the relationship between MTB and the disciplining role of 
debt, based on the idea that companies with a low MTB are more prone to abnormal investment, calling them poorly managed companies. The authors theorize that companies with a low MTB will experience a greater impact of the disciplining role of debt than companies with a high MTB; that is, they make more abnormal investments and reduce them more when debt is issued.

Their results confirm that the two groups hold excessive cash flow values and are subject to changes in cash flow levels after issuing debt; however, those with a low MTB feel this effect more strongly. After issuing debt, the levels for both groups return to being similar to the sector benchmark.

For Jensen (1986), issuing debt to control managers will not always have a positive result. It will be especially relevant for those companies in which there is a greater chance of cash flow wastage, which are exactly the firms that generate a lot of cash flow, but do not have many prospects to continue growing. The effect may not be good for companies that are growing a lot but lack cash flow.

The agency problems and costs are various and not only between managers and shareholders, but also between shareholders and creditors. These include costs of drawing up contracts, manager monitoring expenses for shareholders, and shareholder wealth reduction due to poor management decisions (Jensen \& Meckling, 1976; Saito \& Silveira, 2008). Jensen and Meckling (1976) believe that not only debt can reduce some of these conflicts, but also monitoring and appropriate contractual clauses, incentive programs, and internal and external audits, among others. Using various mechanisms at the same time may lead to better results.

\subsection{Hypothesis Construction}

By developing a competitive equilibrium model of capital structure and industrial dynamics, among other points, Miao (2005) initially assumes that the choice of capital structure reflects the trade-off between the tax benefits of debt and the bankruptcy and agency costs. In his model, company decisions related to financing, investment, entry, and exit are subject to idiosyncratic technological shocks; that is, they are related to productivity.

For Miao (2005), high growth sectors have a lower leverage and turnover rate because the financing and production decisions together influence the number of existing companies and their chances of survival. The author notes that the empirical studies that relate capital structure and investment, entry, and exit decisions reach conclusions such as the negative relationship between investment and debt and between debt and production.

The Miao (2005) model is developed under the premise that the environment is risk-neutral and that firms are identical before their productivity shocks and will differ in how the effects of these shocks take place. If there is an increase in technology, cash flow will consequently be affected due to the increase in operating profit. Growth will also have an option effect, since it changes the expected valuation and increases the company's value and its benefit from continuing in the market. If there is an increase in the firm's value, with lower leverage, it is expected to have a lower default cost and lower expected bankruptcy costs.

High growth for the author corresponds to large growth opportunities, that is, a high MTB. Firms that survive have high productivity (a high technological level); hence a high growth sector has a large number of efficient firms.

Trade-off theory says that in these growth conditions a firm should issue more debts; however, according to Miao (2005), there are empirical studies that do not confirm the prediction that high growth firms have high leverage. Agency theory, for example, says that it is companies with few growth opportunities that will have high debt levels, which is linked to the control of abnormal investment hypothesis.

Thus, the hypothesis of this article is: firms that have abnormal growth above the mean for their sector will have lower leverage.

As seen, due to their investment opportunities with a positive NPV, high growth companies have fewer funds available in cash flow, which reduces the conflict with the managers. Companies with few investment opportunities and available cash flow can alleviate these conflicts by issuing debts (Jensen, 1986). Empirical studies already show this negative relationship between investment opportunities and leverage (Kayo \& Kimura, 2011). The contribution of this article will be in the way it constructs the variable that incorporates the existence of probable positive idiosyncratic shocks and the model used. 


\section{METHODOLOGY}

\subsection{Data and Sample}

If a positive idiosyncratic shock to a firm's investment opportunities, which represents abnormal growth, results in a reduction in the level of debt and an increase in its profitability, the firm could see its market value increase (Miao, 2005). Abnormal growth was measured by the Tobin's $Q$ of firm $i$ in relation to the mean Tobin's $Q$ of the sector, excluding firm $i$. A positive value greater than 1 in this ratio may indicate that the firm experienced positive individual shocks and had investment opportunities that the other companies in the sector did not.

Due to their positive NPV investment opportunities, high growth companies have lower cash flow, which reduces the conflict with managers. Companies with few investment opportunities and available cash flow could alleviate these conflicts by issuing debts (Jensen, 1986). The model and the construction of the variable that represents the positive shocks experienced by companies are contributions of the study to advancing this topic.

In this article, we used Brazilian company data available from the Capital IQ database, excluding financial and regulated companies, covering 1995 to 2016. One of the advantages of panel data is that they enable the adjustments occurring in financial and economic indicators to be included (Marques, 2000), and the dynamic relationships can be represented by using a lagged variable as a regressor. There are around 20 years of data and, according to Flannery and Hankins (2013), the longer the period, the lower the correlation between the lagged dependent variable and the error term.

Companies with a negative equity and the sectors that presented only one company in the database were removed and all the variables were winsorized at 1 and $99 \%$ to reduce the impact of outliers. After these modifications, 70 sectors, 259 companies, and 5,442 observations were left.

\subsection{Method}

Using dynamic panel data models to address corporate finance problems leads to potential problems and limitations of the main methods, and Flannery and Hankins (2013) sought to test the most widely known ones to help researchers in choosing the most appropriate estimation method. Finding the most appropriate method is important given the different results for the same question, such as in the speed of adjustment of capital structure, seen in the theoretical literature review section.

Among the econometric evolutions mentioned by Flannery and Hankins (2013) to reduce or avoid the main biases are instrumental variables, GMM estimators, and long-term trend (LT) and polarization reduction formulas. The methods tested by them to estimate dynamic panel data models were two that by then were considered limited - ordinary least squares (OLS) and fixed effects (FE) and five others considered to be more sophisticated $-A B$, $\mathrm{BB}$, long differencing (LD), four period long differencing (LD4), and the bias-corrected least squares dummy variable approach (LSDVC).

Using OLS to estimate coefficients of the lagged variable in a dynamic panel is not advisable, since there is the correlation bias between the FE and the lagged dependent variable.

FE are used as a control for unobservable characteristics that are invariant in time. However, the combination of a lagged dependent variable and FE can create a substantial bias for short or unbalanced panels. They perform well in the presence of a second-order correlation, but present more errors in the presence of lagged variables.

The GMM of Arellano and Bond (1991) (AB) instrumentalizes the model by using level lagged variables, but presents a greater error in the presence of endogenous variables.

The $\mathrm{BB}$ estimator is an improved version of $\mathrm{AB}$ as it estimates a system of two equations of the regression in levels and in first differences. The advantages are the better performance given an unbalanced panel, endogeneity, and serial correlation. The BB system GMM also increases the number of instruments and reduces the bias given a panel with a reduced quantity of periods.

The LSDVC method assumes that the regressors are strictly exogenous; it is the best method if there is low endogeneity, which is not the reality of the finance databases.

In light of the above, the methods chosen were the Blundell and Bond (1998) GMM and the Arellano and Bond GMM to compare the results. With the main aim of analyzing the effect of a variation in debt in relation to 
the variation in company value, these two methods enable the analysis of this variation using the first differences and control the effect of lagged debt, reducing the omittedvariable bias. As it includes specific company effects and time dummies, it is more efficient against endogeneity than only using an instrumental variable not correlated with the error, which is a problem that using lagged debt can create (Nakamura et al., 2007). An additional result derived from using these models is that it calculates the speed of adjustment of the capital structure.

\subsection{Model}

With the model represented in equation 1 , it is expected to be shown that growth, which increases the firm's value, results in a reduction in leverage, thus contradicting trade-off theory and confirming agency theory. Therefore, the coefficient of interest is $\delta \beta$, which will represent the firm's growth in relation to the sector's growth; the greater the firm's growth, the lower the leverage indicator Lev is expected to be.

$$
\operatorname{Lev}_{i, t}=(1-\delta) \operatorname{Lev}_{i, t-1}+\delta \beta \cdot \frac{\text { tobinq }_{i, t}}{\text { tobinq }_{j-i, t}}+\delta \gamma \cdot X_{i, t}+a_{i, t}+u_{i}
$$

in which $L e v_{i, t}$ is the leverage level of company $i$, in period $t, \delta$ is the coefficient of the lagged dependent variable, $(1-\delta)$ is the speed of adjustment of the capital structure, $L e v_{t-1}$ is the leverage level of firm $i$ in the previous period, $\delta \beta$ is the coefficient of interest of the model, the firm's growth coefficient, $\frac{\text { tobinq }_{i, t}}{\text { tobinq }_{j-i, t}}$ is the ratio between the growth opportunity of company $i$ in period $t$ and the growth opportunities of sector $j$, excluding firm $i$, in period $t$. This is the variable that should show that the firm's abnormal growth will result in a reduction in the level of debt. A positive value greater than 1 in this ratio may indicate that the firm experienced positive individual shocks and had investment opportunities that the other companies in the sector did not. According to Miao (2005), these high growth companies have a lower leverage and see an increase in their value. With the increase in value and lower leverage, a lower default cost and lower expected bankruptcy costs are foreseen. $\delta \gamma$ are the coefficients of the control variables, $X_{i, t}$ is the vector of the control variables of firm $i$, in period $t$, related to the capital structure, $a_{i, t}$ are the FE, and $u_{i, t}$ is the error term. Using the $\mathrm{AB}$ and $\mathrm{BB}$ estimators, three lags were defined, at most, as an instrument of Lev $_{t-1}$. The endogenous variables is $\frac{\text { tobinq }_{i, t}}{\text { tobinq }_{j-i, t}}$, with a maximum of two lags as instruments and a two-step estimator, with standard error correction (Windmeijer, 2005). As in previous studies, such as that of Flannery and Rangan (2006), the X represents variables traditionally related to capital structure that are considered to be exogenous in this model, which are the profitability, tangibility, depreciation, sector leverage, and size variables. The model also includes time dummies.

Sargan tests of overidentifying restrictions were conducted in the two models and the $\mathrm{AB}$ serial correlation test was carried out to increase the reliability regarding the validity of the instruments and the non-existence of a second-order correlation, respectively. The results of these tests are for the models without the standard error correction.

\subsection{Construction of the Variables of the Model}

\subsubsection{Market leverage}

This represents the firm's leverage and is the ratio between total debt and the sum of total debt and market value. The decision was made to only use market leverage and not book leverage as it was verified that studies such as those by Flannery and Rangan (2006) and Huang and Ritter (2009), which used partial adjustment models for the two types of leverage, obtained very similar coefficients $(L E V=T D /(T D+M V))$.

\subsubsection{Tobin $Q_{i}$}

This represents the growth opportunities of firm $i$ and is the ratio between the sum of the market value and total debt and the total assets.

The conceptual definition of the Tobin's $Q$ is the ratio between the company's market value and the replacement value of its assets. According to Famá and Barros (2000), this indicator is a rich measure that enables a series of interpretations and, for this reason, is used in different types of studies, such as on capital investments and monopoly power, as a proxy for value or performance, among others.

In this study, the $\mathrm{Q}$ will represent the company's growth opportunities. A Q higher than 1 shows that the company has an incentive to invest, because this investment is being evaluated by the market as greater than its true cost; but if $\mathrm{Q}<1$, the market believes that the investment has a lower value than its cost (Famá \& Barros, 2000).

An ideal Tobin's Q calculation is practically unfeasible, given that the portion of the value of the third-party capital should be obtained for each company individually based on a secondary market for trading short and longterm securities. For this reason, the studies on finance usually simplify by using accounting and market data available from the main databases (Famá \& Barros, 2000) $(T O B I N Q=(T D+M V) / T A)$. 


\subsubsection{Tobin $Q_{j}$}

This represents the growth opportunities of sector $j$. It is the tobin $Q$ measure of the firms participating in sector $j$ each year, excluding firm $i$. The more a firm's tobin $Q$ is above its sector's $\mathrm{Q}$, the higher its growth and its value. This shows that the firm experienced a shock that brought investment opportunities that the others did not have. This will be considered a high growth firm.

The sector is a determinant of the capital structure, given that factors such as its mean leverage and assets influence the firms' financing decisions (Degryse, De Goeij \& Kappert, 2012; Leary \& Roberts, 2014). The sector is often used as a benchmark for the firm's operations, since many characteristics of firms in the same competitive environment may converge in normal conditions. The sector's mean values are also usually used to represent unobservable environmental factors in the construction of empirical models. In this article, if compared with the sector, a firm that has more growth opportunities is considered to have experienced some positive shock that its peers did not.

The environment of the sector influences investment and financing decisions and its stage of life will also affect the available investment opportunities and the needs for resources of the participating firms - not only financial ones, but also operational and human (Maksimovic \& Phillips, 2008).

\subsubsection{Profitability}

This is a representation of the firm's profitability in the period and the ratio between earnings before interest and tax and total assets. Depending on the theory, whether trade-off or pecking order, the relationship with leverage can be positive or negative, respectively (Fama \& French,
2002). According to inertia theory, the most lucrative firms will have less debt $($ Welch, 2004) $($ PROFIT $=$ EBIT / TA $)$.

\subsubsection{Tangibility}

This represents the firm's tangibility and was constructed from the ratio between fixed and total assets; a positive relationship with leverage is expected due to its collateral role (Almeida \& Campello, 2007) $(T A N G=P P E / T A)$.

\subsubsection{Size}

This represents the firm's size and was constructed with the natural logarithm of the real value of sales. The relationship of this variable with leverage is traditionally positive (Byoun, 2008), but Miao (2005) believes that the smallest firms could be more leveraged. One property of his theoretical model says that, even if the firms are identical ex ante and for this reason pay the same interest rate, they will have different leverage levels. The smallest or inefficient companies will have greater leverage because the surviving, most efficient companies react to the shock differently, keeping their leverage lower to have higher equity values, believing in the inverse relationship between value and leverage. In this theoretical model, the author is addressing manufacturing companies, which are more tangible. Thus, cases such as startups, which are normally smaller, may not fit this characterization, given that they almost always use their own capital for financing (Robb \& Robinson, 2014) $($ SIZE $=$ LN $($ SALES $))$.

\subsubsection{Depreciation}

This is the value of the depreciation in relation to total assets. Firms with higher depreciation expenses have less need for the tax deductions derived from debt (Flannery \& Rangan, 2006) $(D E P=D E P / T A)$.

\section{RESULTS AND DISCUSSION}

\subsection{Descriptive Statistics}

Table 1 presents the descriptive statistics for the sample used in this study. It also shows the means, medians, and standard deviation for all the companies. The market and book leverage of the companies in the sample in the period between 1995 and 2016 exceeds 30\%. Short and long-term debts are included in this construction. The Tobin's Q, which represents the company's growth opportunities, had a mean value of 0.93 ; that is, the market value added to total debts is almost equal to the value of the assets of these companies, on average, while the median is 0.62 .

The mean size of the companies is greater than one billion reais, while the tangibility is 0.34 , with a high standard deviation (0.32) and mean depreciation of $3 \%$ for the whole sample. 
Table 1

Descriptive statistics

\begin{tabular}{|c|c|c|c|c|c|}
\hline & & Obs. & Mean & Standard deviation & Median \\
\hline MarketLev & $\mathrm{TD} / \mathrm{TD}+\mathrm{MV}$ & 2,434 & 0.34 & 0.25 & 0.30 \\
\hline AccountingLev & $\mathrm{TD} / \mathrm{TA}$ & 3,421 & 0.35 & 0.23 & 0.33 \\
\hline TobinQ & $\mathrm{TD}+\mathrm{MV} / \mathrm{TA}$ & 2,602 & 0.93 & 1.03 & 0.62 \\
\hline Size & Log (Sales) & 3,603 & $1,144.8$ & 8.1 & $1,299.0$ \\
\hline Tangibility & PPE/TA & 1,716 & 0.34 & 0.32 & 0.26 \\
\hline Profitability & EBIT/TA & 3,732 & 0.06 & 0.09 & 0.05 \\
\hline Depreciation & DEP/TA & 3,476 & 0.03 & 0.03 & 0.03 \\
\hline
\end{tabular}

Note: Sample of Brazilian companies taken from the Capital IQ database, 1995-2016, excluding financial and regulated ones. The revenue data were corrected by the National Extended Consumer Price Index (IPCA) to construct the Size variable. Companies with a negative equity and the sectors that present only one company in the database were removed, and all the variables were winsorized at 1 and 99\%.

$D E P=$ depreciation; $E B I T=$ earnings before interest and tax; $M V=$ market value; PPE = plant, property, and equipment; $T A=$ total assets; $T D=$ total debt.

Source: Elaborated by the authors.

\subsection{Application of the Model}

The results available in Table 2 show that, using the $\mathrm{BB}$ and $\mathrm{AB}$ methods, when the firm is high growth in relation to its sector this will cause a drop in its leverage $\left(-0.001^{* * *}\right)$. The more the firm's growth opportunities vary above the mean for the sector, the lower its leverage will be. The coefficient of the tobin $Q_{i} /$ tobin $Q_{j}$ ratio, with $99.9 \%$ significance according to $\mathrm{BB}$, shows that an increase/ reduction in this indicator will reduce/increase the firm's leverage.

This result supports the conclusions of studies such as those of Berens and Cuny (1995) and Miao (2005), which affirm that growth and value are negatively related with the firm's leverage. This negative relationship can also be interpreted as being one in which when firms have few investment opportunities they will issue more debts.

Although the statistical significance of this variable was high, the economic significance may be questionable. The standard deviation of the first difference of the tobin $Q /$ tobinQ_IND variable was 1.99 . Thus, a standard deviation increase in tobin $Q /$ tobinQ_IND leads to a reduction in indebtedness of 0.2 percentage points $(-0.001 \times 1.99)$. Despite the low economic significance, the high statistical significance suggests that the effect of this variable is not negligible, and so should be explored more in future studies.

By using the partial adjustment model to address the main research question, an additional result can be analyzed: the speed of adjustment of the leverage. Unlike the coefficient of interest, which had the same result in the two methods, the speed of adjustment $(1-\delta)$ differs considerably between them. The BB method, which is considered more reliable, shows that the companies' capital structure is adjusted by $56 \%$ p.a., while the result of the $\mathrm{AB}$ method shows the firms adjusting $83 \%$ of their leverage each period. This $A B$ speed of adjustment is more than double that of the studies that analyze the adjustment in other countries, such as those of Flannery and Rangan (2006) and Huang and Ritter (2009), but differs less from Brazilian studies, such as that of Kayo, Brunaldi, and Aldrighi (2018), which found, for nonfamily firms, a speed of adjustment of $48 \%$ p.a. with the BB method and $75 \%$ p.a. with $\mathrm{AB}$.

The choice of the control variables for the model followed recent studies on capital structure that use a partial adjustment model. To verify the explanatory power of these in terms of leverage, they were also tested using multiple regression in the static model, with and without the coefficient of interest of the main model. Table 3 presents the results. The model that relates market leverage with the industry's current leverage values, size, tangibility, and depreciation has an $\mathrm{R}^{2}$ of $28 \%$; when the coefficient of tobin $Q_{i} /$ tobin $Q_{j}$ is included, the explanatory power rises to $31 \%$.

Among these variables, both in the partial adjustment dynamic model (Table 2) and in the static model (Table 3 ), those that stand out are profitability, size, and sector leverage. Regarding profitability, and confirming Welch (2004), the most lucrative firms will have a lower leverage. This result also aligns with Bastos and Nakamura (2009) 
when they affirm that pecking order is the theory that works best for the Brazilian company data. Industry leverage, as demonstrated by Mackay and Phillips (2005) and Leary and Roberts (2014), was shown to be strongly and positively related with the firm's market leverage.
The Sargan and Arellano and Bond (1991) reliability tests, available in Table 2, increase the reliability regarding the validity of the instruments and regarding the nonexistence of a second-order correlation, respectively.

Table 2

Application of partial adjustment models

\begin{tabular}{|c|c|c|}
\hline Leverage & BB & $A B$ \\
\hline \multirow{2}{*}{ Leverage. $L 1}$. & $0.436^{* * *}$ & $0.163^{*}$ \\
\hline & $(0.080)$ & $(0.091)$ \\
\hline \multirow{2}{*}{ TobinQ/tobinQ_IND } & $-0.001^{* * *}$ & $-0.001^{* *}$ \\
\hline & $(0.000)$ & $(0.000)$ \\
\hline \multirow{2}{*}{ Profitability } & $-0.584^{* * *}$ & $-0.557^{* * *}$ \\
\hline & $(0.151)$ & $(0.141)$ \\
\hline \multirow{2}{*}{ Size } & $0.034^{* * *}$ & $0.040^{* *}$ \\
\hline & (0.009) & $(0.018)$ \\
\hline \multirow{2}{*}{ Tangibility } & -0.012 & $-0.011^{* *}$ \\
\hline & $(0.017)$ & $(0.014)$ \\
\hline \multirow{2}{*}{ Depreciation } & 0.078 & 0.036 \\
\hline & $(0.334)$ & $(0.297)$ \\
\hline \multirow{2}{*}{ Leverage IND } & $0.230^{* * *}$ & 0.135 \\
\hline & $(0.080)$ & $(0.086)$ \\
\hline$(1-\delta)$ & 0.564 & 0.837 \\
\hline Time fixed effects & Yes & Yes \\
\hline Sargantest & 0.0351 & 0.0232 \\
\hline AbTest (1) & 0 & 0.0003 \\
\hline AbTest (2) & 0.2082 & 0.315 \\
\hline Companies & 212 & 202 \\
\hline Obs. & 1,878 & 1,576 \\
\hline
\end{tabular}

Note: Presentation of the results of equation 1. Sample of Brazilian companies taken from the Capital IQ database, 1995-2016, excluding financial and regulated ones. The variables are described in Table 1. The coefficients of the BB column were estimated according to the generalized method of moments (GMM) of Blundell and Bond (1998) and the coefficients of the AB column in accordance with Arellano and Bond (1991). The standard errors were corrected by the WC-robust estimator method of Windmeijer (2005) and are presented in parentheses below each coefficient.

$(1-\delta)=$ speed of adjustment of capital structure; AbTest (1) and (2) = AB serial correlation test; Sargantest = Sargan test of overidentifying restrictions calculated based on the model without WC correction.

$*, * *, * * *=$ statistically significant at $10 \%, 5 \%$, and $1 \%$.

Source: Elaborated by the authors.

Table 3

Determinants of capital structure

\begin{tabular}{lcc}
\hline Y = market leverage & (i) & (ii) \\
\hline \multirow{2}{*}{ Ind_Lev } & $0.207^{* * *}$ & $0.126^{* *}$ \\
\cline { 2 - 3 } & $(0.066)$ & $(0.058)$ \\
\cline { 2 - 3 } Profitability & $-0.588^{* * *}$ & $-0.641^{* * *}$ \\
\hline \multirow{2}{*}{ Size } & $(0.089)$ & $(0.084)$ \\
\cline { 2 - 3 } & $0.035^{* * *}$ & $0.036^{* * *}$ \\
\hline
\end{tabular}


Table 3

Cont.

\begin{tabular}{lcc}
\hline Y $=$ market leverage & (i) & (ii) \\
\hline \multirow{2}{*}{ TobinQ/TobinQ_IND } & $-0.001^{* * *}$ & $-0.238^{*}$ \\
\cline { 2 - 3 } Depreciation & $(0.000)$ & $(0.140)$ \\
\hline \multirow{2}{*}{ Tangibility } & -0.221 & -0.036 \\
\hline \multirow{2}{*}{ Constant } & $(0.144)$ & $(0.028)$ \\
\hline $\mathrm{R}^{2}$ & -0.0415 & 0.057414 \\
\hline $\mathrm{N}$ & $(0.029)$ & $(0.068)$ \\
\hline Companies & 0.063 & 0.28 \\
\hline Time fixed effects & $(0.076)$ & 1,348 \\
\hline
\end{tabular}

Note: These are the results of the test of the relationship between market leverage and its main determinants. The sample is the same as the one used in the application of the model available in Table 1. Column (i) is the model that considers as an independent variable the ratio between the firm's growth opportunities and the sector's growth opportunities. Column (ii) represents the model without the inclusion of this variable that provides the coefficient of interest of the main model.

Source: Elaborated by the authors.

The tables of the robustness tests will not be presented for space reasons, but it can be affirmed that the results found remain similar, even considering two different constructions of the leverage indicator and two different constructions of the firm's abnormal growth indicator. The same occurs after using the sector median as a reference instead of the sector mean.

To better understand if there is a particular group of companies where there is a greater negative impact of growth on leverage, the general sample was separated into the most and least profitable, the most and least leveraged, and the overvalued and undervalued firms, always in relation to the mean sector value in the year, excluding firm $i$. The results are available in tables 4 and 5 .

\subsubsection{Impact of growth opportunities and speed of} adjustment of capital structure for the most and least leveraged companies

The first column of Table 4 shows that the coefficient of the dummy variable that represents the companies with leverage above the mean is positive and significant (Lev > Mean lev; $0.176^{* * *}$ ). This may indicate that the negative effect of the relationship between growth and leverage is smaller for this group in relation to the least leveraged ones, since the relationship between growth opportunities and leverage is equal to the results of the general model.

Financial flexibility plays a relevant role in investment and financing decisions (Denis \& McKeon, 2012). If the company's leverage is at a level higher than the sector mean, it may be close to its debt capacity. Lemmon and Zender (2010) say that highly leveraged firms, without debt capacity, need to reduce this volume to obtain more loans; if this does not occur, it will be necessary to issue more shares to finance an investment. By being close to the limit, their bankruptcy costs are higher; however if the company is highly valued (high Tobin's Q), it may not be advantageous or may be very costly to intensify the movement of reducing its debts and returning to the level at which there is available debt capacity.

What may help to understand why this negative effect is less intense for the most leveraged firms is the information in panel A of Table 5, which shows that the speed of adjustment is greater for less leveraged companies. This result is the opposite of what Flannery and Rangan (2006) found for American companies. In this study, the most leveraged firms would have a speed of $64 \%$ p.a., while the least leveraged ones adjust by $94 \%$ p.a. If the companies are in the same sector, they are expected to have similar risk conditions and pay similar interest rates; but comparing these two groups that are in similar conditions shows evidence that it may be less costly for less leveraged Brazilian companies to take on debt or buy back shares than for more leveraged ones to reduce their debts or increase their equity. For this reason, the least leveraged ones would be able to make the adjustment faster. 
4.2.2 Impact of growth opportunities and speed of adjustment of capital structure for the over and undervalued companies

The second column of Table 4 shows that the coefficient of the dummy variable that represents the group of companies with growth opportunities above the mean is negative, but not significant (-0.0197).

It was expected that, for companies that have a higher Tobin's $Q$ ratio than the mean of their peers, any potential increase would have a marginal impact on their debt compared to those with the opposite reality, and be less valued than the sector mean, since reducing leverage is a way of protecting future growth opportunities (Flannery \& Rangan, 2006). According to Baker and Wurgler (2002), the managers of an undervalued company would increase their leverage by buying back shares. The results for the speed of adjustment of capital structure, available in panel B of Table 5, show that the overvalued ones (59\%) also adjust more quickly than the undervalued ones (49\%).

\subsubsection{Impact of growth opportunities and speed of} adjustment of capital structure for the most and least profitable companies

The third column of Table 4 shows that the dummy Prof $>$ MeanProf, which represents the group of companies whose profitability is above the mean, has a negative, but also non-significant value (-0.009). It was expected that, for these companies, the effect of a reduction in leverage, caused by growth, would be bigger, since these firms may prioritize using their own funds for financing, reinforcing the idea that the more profitable the firm, the more highly valued it is and the lower the level of leverage.

The speed of adjustment of the capital structure in these two groups, available in panel $\mathrm{C}$ of Table 5, is shown to be greater for companies with profits below the sector mean, at $59 \%$ p.a., in relation to those that have profitability above the mean, at $51 \%$ p.a., according to the system GMM method. This is possibly because despite the most lucrative ones having more resources available to adjust if they are outside the level that is considered optimal, the least profitable ones may suffer some type of restriction if they are outside the standard. For example, a less profitable firm with high leverage may have difficulties in obtaining new loans to take advantage of some investment opportunity, and therefore this group of companies may seek to adjust more quickly than those that can self-finance with their own funds and, for that reason, will have fewer difficulties.

Table 4

Effect of abnormal growth over leverage by groups

\begin{tabular}{|c|c|c|c|}
\hline & Overleveraged & Overvalued & High profitability \\
\hline \multirow{2}{*}{ Leverage L1. } & $0.344^{* * *}$ & $0.436^{* * *}$ & $0.434^{* * *}$ \\
\hline & $(0.065)$ & $(0.080)$ & $(0.081)$ \\
\hline \multirow{2}{*}{ TobinQ/TobinQ_IND } & $-0.001^{*}$ & $-0.001 * * *$ & $-0.001^{* * *}$ \\
\hline & $(0.000)$ & $(0.000)$ & $(0.000)$ \\
\hline \multirow{2}{*}{ Profitability } & $-0.342^{* * *}$ & $-0.581 * * *$ & $-0.548^{* * *}$ \\
\hline & $(0.113)$ & $(0.153)$ & $(0.161)$ \\
\hline \multirow{2}{*}{ Size } & $0.018^{* *}$ & $0.035^{* * *}$ & $0.034^{* * *}$ \\
\hline & $(0.008)$ & $(0.009)$ & $(0.009)$ \\
\hline \multirow{2}{*}{ Tangibility } & -0.011 & -0.01 & -0.011 \\
\hline & $(0.014)$ & $(0.017)$ & $(0.017)$ \\
\hline \multirow{2}{*}{ Depreciation } & 0.248 & 0.085 & 0.096 \\
\hline & $(0.169)$ & $(0.34)$ & $(0.331)$ \\
\hline \multirow{2}{*}{ Lev IND } & $0.394^{* * *}$ & $0.229 * * *$ & $0.235^{* * *}$ \\
\hline & $(0.077)$ & $(0.077)$ & $(0.078)$ \\
\hline \multirow{2}{*}{ Lev $>$ Mean lev } & $0.176^{* * *}$ & - & - \\
\hline & $(0.023)$ & & \\
\hline \multirow{2}{*}{$Q>$ Mean $Q$} & - & -0.0197 & - \\
\hline & & $(0.016)$ & \\
\hline \multirow{2}{*}{ Prof $>$ Mean prof } & - & - & -0.009 \\
\hline & & & $(0.011)$ \\
\hline
\end{tabular}




\section{Table 4}

Cont.

\begin{tabular}{lccc}
\hline & Overleveraged & Overvalued & High profitability \\
\hline$(1-\delta)$ & 0.656 & 0.564 & 0.566 \\
\hline Sargantest & 0.0669 & 0.0327 & 0.0355 \\
\hline AbTest $(1)$ & 0 & 0.0001 & 0 \\
\hline AbTest (2) & 0.2872 & 0.2170 & 0.2048 \\
\hline Companies & 212 & 212 & 212 \\
\hline Obs. & 1,878 & 1,878 & 1,878 \\
\hline
\end{tabular}

Note: Presentation of the results of equation 1 with the inclusion of dummies that represent, in the first column, the group of companies above the sector leverage (Lev > Mean lev). In the second column are the results for the group of companies above the sector Tobin's Q (Q > Mean Q) and in the third column are the results for the groups of companies above the sector profitability (Prof > Mean prof). All the regressions include time fixed effects. The samples of Brazilian companies were taken from the Capital IQ database, 1995-2016, excluding financial and regulated ones. The variables are the same as those used and described in Table 1. The coefficients were estimated with the system generalized method of moments (GMM) of Blundell and Bond (1998). The standard errors were corrected using the WC-robust estimator method of Windmeijer (2005) and are presented in parentheses below each coefficient.

$(1-\delta)=$ speed of adjustment of capital structure; AbTest (1) and (2) = Arellano and Bond (1991) serial correlation test; Sargantest = Sargan test of overidentifying restrictions calculated based on the model without WC correction.

$*, * *, * * *=$ statistically significant at $10 \%, 5 \%$, and $1 \%$.

Source: Elaborated by the authors.

Table 5

Speed of adjustment of capital (SOA) by groups

\begin{tabular}{|c|c|c|}
\hline & \multicolumn{2}{|c|}{ Panel A } \\
\hline & Overleveraged & Underleveraged \\
\hline SOA & 0.63 & 0.945 \\
\hline \multirow{2}{*}{ Leverage. $L 1$. } & $0.37^{* * *}$ & 0.055 \\
\hline & $(0.089)$ & $(0.154)$ \\
\hline Coefficient of interest & Yes & Yes \\
\hline Control variables & Yes & Yes \\
\hline Time fixed effects & Yes & Yes \\
\hline Sargantest & 0.1834 & 0.9026 \\
\hline AbTest (1) & 0 & 0.0001 \\
\hline AbTest (2) & 0.277 & 0.23 \\
\hline Company & 177 & 139 \\
\hline \multirow[t]{3}{*}{ Obs. } & 1,227 & 651 \\
\hline & \multicolumn{2}{|c|}{ Panel B } \\
\hline & Overvalued & Undervalued \\
\hline SOA & 0.592 & 0.495 \\
\hline \multirow{2}{*}{ Leverage. $L 1}$. & $0.408^{* * *}$ & $0.505^{* * *}$ \\
\hline & $(0.101)$ & $(0.077)$ \\
\hline Coefficient of interest & Yes & Yes \\
\hline Control variables & Yes & Yes \\
\hline Time fixed effects & Yes & Yes \\
\hline Sargantest & 0.5622 & 0.9315 \\
\hline AbTest (1) & 0.0001 & 0 \\
\hline AbTest (2) & 0.4289 & 0.2148 \\
\hline Companies & 194 & 139 \\
\hline Obs. & 1,290 & 588 \\
\hline
\end{tabular}


Table 5

Cont.

\begin{tabular}{|c|c|c|}
\hline & \multicolumn{2}{|c|}{ Panel C } \\
\hline & High profitability & Low profitability \\
\hline SOA & 0.515 & 0.594 \\
\hline \multirow{2}{*}{ Leverage. $L 1$. } & $0.485^{* *}$ & $0.406^{* * *}$ \\
\hline & $(0.253)$ & $(0.134)$ \\
\hline Coefficient of interest & Yes & Yes \\
\hline Control variables & Yes & Yes \\
\hline Time fixed effects & Yes & Yes \\
\hline Sargantest & 0.7255 & 0.6296 \\
\hline AbTest (1) & 0 & 0.0115 \\
\hline AbTest (2) & 0.1982 & 0.378 \\
\hline Companies & 165 & 173 \\
\hline Obs. & 924 & 954 \\
\hline
\end{tabular}

Note: Presentation of the results of equation 1 by subgroups. The samples of Brazilian companies were taken from the Capital IQ database, 1995-2016, excluding financial and regulated ones. The variables are the same as those used and described in Table 1. The coefficients were estimated using the system generalized method of moments (GMM) of Blundell and Bond (1998). The standard errors were corrected using the WC-robust estimator method of Windmeijer (2005) and are presented in parentheses below each coefficient. Panel A presents the results for the groups of companies above and below the sector leverage, panel $B$ presents the results for the groups of companies above and below the sector Tobin's $Q$, and panel $C$ presents the results for the groups of companies above and below the sector profitability. All the regressions include time fixed effects.

AbTest (1) and (2) = Arellano and Bond (1991) serial correlation test; Sargantest = Sargan test of overidentifying restrictions calculated based on the model without WC correction; SOA = speed of adjustment of capital structure.

$*, * *, * * *$ statistically significant at $10 \%, 5 \%$, and $1 \%$

Source: Elaborated by the authors.

\section{CONCLUSIONS}

The aim of this paper was to investigate whether the firms with high growth in relation to the companies from their sector have lower leverage levels. High growth was represented by the firm's growth opportunities in relation to the mean for its sector. The main results suggest that this negative relationship exists: if there is an increase in the ratio between the growth opportunities of firm $i$ in relation to the growth opportunities of its sector $j$, its leverage indicators will be reduced; if there is a fall in the growth opportunities ratio, there will be an increase in leverage.

The mediator of this relationship is the firm's value. Miao (2005) believes that high technological growth firms may see their cash flow compromised in the short term, but their profitability is higher, leading to an increase in value. For the author, the most efficient firms aim to keep their leverage levels lower and agency theory says that firms with low investment opportunities will issue debts as a way of preventing their managers from misusing the firm's resources and reducing its value. In practice, these results suggest that, for the most efficient firms, this negative relationship reduces bankruptcy cost and, for the least efficient ones, it reduces agency costs.
In this study, the negative relationship between growth and leverage is robust for different constructions of the indicator of the dependent variable and of the endogenous variable. The negative effect is stronger for the least leveraged companies, but it was not possible to prove that it is also stronger for the most profitable and for the overvalued ones.

As an additional result, the partial adjustment model enables an analysis of the speed of adjustment of the capital structure. The main results show that the Brazilian firms adjust their leverage by $56 \%$ and $83 \%$ a year, according to the $\mathrm{BB}$ and $\mathrm{AB}$ methods, respectively. In relation to other studies, these values are high. For Brazilian company data covering 1999 to 2003, Nakamura et al. (2007) found a low speed of adjustment and explained that it is a reflection of the high interest rates and difficult access to credit. Thus, the high speed of adjustment shown in this study, which uses data up to 2016, may be a reflection of the change in this economic scenario, as interest rates became lower and credit-facilitating policies were implemented after 2003. If separated into groups, the underleveraged, overvalued, 
and least profitable companies adjust more quickly than the overleveraged, undervalued, and most profitable ones; for these company profiles, the adjustment process may be less costly as they have a higher available debt capacity and own funds available, or even without such availability, being outside the optimal level may lead to more serious implications than the adjustment effort.

The main limitation of this study lies in the need to use a proxy to represent the possible "extra" investment opportunities that the firms had in relation to their sectors, especially when the Tobin's Q is used, which is found in different types of studies, representing different characteristics. Thus, due to its ambiguity, the interpretations of the results, when using the Tobin's $\mathrm{Q}$, should be more cautious. For the future, the ideal scenario would be to analyze, in a more meticulous and manual way, the behavior of the main sectors and find, for Brazil, those companies that experienced positive technological shocks and stood out in this way in relation to their peers.

\section{REFERENCES}

Almeida, H., \& Campello, M. (2007). Financial constraints, asset tangibility, and corporate investment. The Review of Financial Studies, 20(5), 1429-1460.

Alti, A. (2006). How persistent is the impact of market timing on capital structure? The Journal of Finance, 61(4), 1681-1710.

Arellano, M., \& Bond, S. (1991). Some tests of specification for panel data: Monte Carlo evidence and an application to employment equations. The Review of Economic Studies, 58(2), 277-297.

Baker, M., \& Wurgler, J. (2002). Market timing and capital structure. The Journal of Finance, 57(1), 1-32.

Bastos, D. D., \& Nakamura, W. T. (2009). Determinantes da estrutura de capital das companhias abertas no Brasil, México e Chile no período 2001-2006. Revista Contabilidade \& Finanças, 20(50), 75-94.

Berens, J. L., \& Cuny, C. J. (1995). The capital structure puzzle revisited. The Review of Financial Studies, 8(4), 1185-1208.

Blundell, R., \& Bond, S. (1998). Initial conditions and moment restrictions in dynamic panel data models. Journal of Econometrics, 87(1), 115-143.

Byoun, S. (2008). How and when do firms adjust their capital structures toward targets? The Journal of Finance, 63(6), 30693096.

D’Mello, R., \& Miranda, M. (2010). Long-term debt and overinvestment agency problem. Journal of Banking \& Finance, 34(2), 324-335.

Degryse, H., De Goeij, P., \& Kappert, P. (2012). The impact of firm and industry characteristics on small firms' capital structure. Small Business Economics, 38(4), 431-447.

Denis, D. J., \& McKeon, S. B. (2012). Debt financing and financial flexibility evidence from proactive leverage increases. Review of Financial Studies, 25(6), 1897-1929. https://doi.org/10.1093/ $\mathrm{rfs} / \mathrm{hh}$ 005

Fama, E. F., \& French, K. R. (2002). Testing trade-off and pecking order predictions about dividends and debt. The Review of Financial Studies, 15(1), 1-33.

Famá, R., \& Barros, L. A. B. C. (2000). Q de Tobin e seu uso em finanças: aspectos metodológicos e conceituais. Caderno de Pesquisas em Administração, 7(4), 27-43.

Fischer, E. O., Heinkel, R., \& Zechner, J. (1989). Dynamic capital structure choice: Theory and tests. The Journal of Finance, 44(1), 19-40.
Flannery, M. J., \& Hankins, K. W. (2013). Estimating dynamic panel models in corporate finance. Journal of Corporate Finance, 19(2013), 1-19.

Flannery, M. J., \& Rangan, K. P. (2006). Partial adjustment toward target capital structures. Journal of Financial Economics, 79(3), 469-506.

Huang, R., \& Ritter, J. (2009). Testing theories of capital structure and estimating the speed of adjustment. Journal of Financial and Quantitative Analysis, 44(2), 237-271.

Jensen, M. C. (1986). Agency costs of free cash flow, corporate finance, and takeovers. The American Economic Review, 76(2), 323-329.

Jensen, M. C., \& Meckling, W. H. (1976). Theory of the firm: Managerial behavior, agency costs and ownership structure. Journal of Financial Economics, 3(4), 305-360.

Kayo, E. K., Brunaldi, E. O., \& Aldrighi, D. M. (2018). Capital structure adjustment in Brazilian family firms. Revista de Administração Contemporânea, 22(1), 92-114.

Kayo, E. K., Kimura, H. (2011). Hierarchical determinants of capital structure. Journal of Banking \& Finance, 35(2), 358371.

Kraus, A., \& Litzenberger, R. H. (1973). A state-preference model of optimal financial leverage. The Journal of Finance, 28(4), 911-922.

Leary, M. T., \& Roberts, M. R. (2005). Do firms rebalance their capital structures? The Journal of Finance, 60(6), 2575-2619. https://doi.org/10.1111/j.1540-6261.2005.00811.x

Leary, M., \& Roberts, M. (2014). Do peer firms affect corporate financial policy? Journal of Finance, 69(1), 139-178.

Lemmon, M. L., \& Zender, J. F. (2010). Debt capacity and tests of capital structure theories. Journal of Financial and Quantitative Analysis, 45(5), 1161-1187.

Lemmon, M. L., Roberts, M. R., \& Zender, J. F. (2008). Back to the beginning: Persistence and the cross section of corporate capital structure. Journal of Finance, 63(4), 15751608.

MacKay, P., \& Phillips, G. M. (2005). How does industry affect firm financial structure? The Review of Financial Studies, 18(4), 1433-1466.

Maksimovic, V., \& Phillips, G. (2008). The industry life cycle, acquisitions and investment: Does firm organization matter? The Journal of Finance, 63(2), 673-708. 
Marques, L. B. (2000). Modelos dinâmicos com dados em painel: revisão da literatura. Retrieved from http://wps.fep.up.pt/wps/ wp100.pdf

Miao, J. (2005). Optimal capital structure and industry dynamics. The Journal of Finance, 60(6), 2621-2659.

Modigliani, F, Miller, M. H. (1958). The cost of capital, corporation finance and the theory of investment. American Economic Review, 48(3), 261-297, 1958.

Myers, S. C. (1977). Determinants of corporate borrowing. Journal of Financial Economics, 5(2), 147-175.

Nakamura, W. T., Martin, D. M. L., Forte, D., de Carvalho Filho, A. F., da Costa, A. C. F., \& do Amaral, A. C. (2007). Determinantes de estrutura de capital no mercado brasileiro: análise de regressão com painel de dados no período 1999-2003. Revista Contabilidade \& Finanças, 18(44), 72-85.

Robb, A. M., \& Robinson, D. T. (2014). The capital structure decisions of new firms. The Review of Financial Studies, 27(1), 153-179.

Saito, R., \& Silveira, A. D. M. D. (2008). Governança corporativa: custos de agência e estrutura de propriedade. Revista de Administração de Empresas, 48(2), 79-86.

Tobin, J. (1969). A general equilibrium approach to monetary theory. Journal of Money, Credit and Banking, 1(1), 15-29.

Welch, I. (2004). Capital structure and stock returns. The Journal of Political Economy, 112(1), 106-131.

Windmeijer, F. (2005). A finite sample correction for the variance of linear efficient two-step GMM estimators. Journal of Econometrics, 126(1), 25-51. 